This is a self-archived version of an original article. This version may differ from the original in pagination and typographic details.

Author(s): Eskelinen, Teppo

Title: Democracy as Utopia : On Locating Radical Roots

Year: 2020

Version: Accepted version (Final draft)

Copyright: (c) Author \& Zed Books, 2020

Rights: In Copyright

Rights url: http://rightsstatements.org/page/lnC/1.0/?language=en

Please cite the original version:

Eskelinen, T. (2020). Democracy as Utopia : On Locating Radical Roots. In T. Eskelinen (Ed.), The Revival of Political Imagination : Utopia as Methodology (pp. 151-167). Zed Books.

https://doi.org/10.5040/9781350225633.ch.009 


\section{Democracy as Utopia: On Locating Radical Roots}

\section{Teppo Eskelinen}

Utopian thought, by its very nature, implies deviation from what immediately exists. The critical departures from the present taken in utopias can come in the form of alternative futures or in the form of alternative spaces, but they are departures all the same. Yet the relation between utopia and reality, as already noted in this book, is more complex than one of total detachment. Utopias can be more or less 'realistic' (Wright 2010), in the sense that their realisation seems plausible without complete undoing of the society as we know it; and they can be more or less 'facilitating' (Levitas 2010), in the sense of being relevant for animating transformative social movements and initiatives here and now.

Yet the relation between utopia and reality can also be approached from a third possible direction: Locating the utopian potential in what ostensibly already exists. Indeed, a large number of radical and transformative ideas have been partially incorporated in the existing social order, recuperated so that their potential to facilitate further transformation is rendered invisible, and eventually captured in the narrative of the current social order being the superior one with no reasonable existing alternatives.

This chapter analyses the matter through the notion of democracy. Arguably no other political concept in contemporary society is, simultaneously, as radical and compromised. The task is to locate the utopian potential of the concept and see the current hegemonic interpretation of democracy as a hybrid form consisting of both democratic and antidemocratic elements. This analysis also shows, that the currently hegemonic liberal capitalist conception of democracy is merely one possible form of democracy, and indeed quite arbitrary from a historical point of view.

Below, I will discuss the hegemonic interpretation of democracy, understood as compatible with and limited by capitalism and individualistic liberalism. Subsequently, I will sketch what a utopian reading of democracy could look like. Thereafter I will move to discuss mechanisms, 
both institutional and cultural, that limit democratic ideas and practices today, along with why democratic discourse needs utopias. This leads to a discussion on saving the utopian potential of concepts and ways forward with deepening democratic practice. The ultimate aim is to show how democracy can be significantly improved when informed by utopian thought.

\section{Limited utopian concepts}

It is fair to say that there exists a given hegemonic democratic practice called liberal capitalist democracy. As noted in the Introduction to this book, this model of democracy is key to the conception of 'the end of history': Victorious to the point of distracting human capacity to conceive of qualitatively better societies. While there is a rich tradition of democratic theories (participatory, communitarian, etc.) and different levels of democratic practice (local, global, etc.), one finds this given uniform model of democracy all over the globe. It is based on nation states as the realm of politics, representation, the popular vote, majority decision-making, constitutionalism, the idea of democracy as mediation between individual rights and government sovereignty, and most importantly the removal of economic matters from the sphere of democracy. While there naturally are minor variations to this model, and one can point to better and worse functioning versions of it, the core model can be said to hold a hegemonic position.

Furthermore, the narrative supporting this hegemonic model sees this particular model as incorporating the spirit of democracy as it has always existed since ancient times. Democracy is then seen as an integral part of the 'liberal capitalist' package, prevailing over grand utopian visions, bringing piecemeal governance and the individual to the forefront in politics.

As always in critiques of hegemony, it needs to be noted how the hegemonic interpretation presents itself as the only, only viable, or natural form, downplaying the possibility or the very existence of other forms. The tendency to see democracy as comfortably aligned with institutions of capitalism and liberalist individualism leads to marginalizing the ostensibly existing variety of 'models of democracy' (Held 2006), to the extent that it can be difficult to 
even recognize the existence of other models. This essentialisation also downplays the possibility of the development of democracy: If the form of democracy is seen to be fixed and democracy is seen to be threatened only by totalitarianisms (often associated with utopian aspirations), it is highly difficult to see the shortcomings of the existing model.

The perhaps most defining feature of the hegemonic conception of democracy is its alignment with capitalism. Liberal capitalist democracy sees democracy and the main capitalist institutions as ontologically attached. Therefore, according to this mode of thought, departures from capitalist institutions (private property, commodified labour, markets, the banking system, universal money) would also practically mean departure from democratic practice.

Another specificity of contemporary capitalism is its attachment to liberal individualism. As noted earlier (see Eskelinen, Lakkala \& Pyykkönen in this volume, also Jameson 1991 on postmodernism), the hegemonic mentality and the mode of governance more generally today lean strongly towards the individual as the focal point. The idea of the self-interested individuals with incompatible wants then becomes easily also a tacit justification for conservatism in relation to existing institutions; indeed individuality is part of the system of how people are governed today.

Following these starting points, it is convenient to land on the conclusion that the threats democracy is facing today, stem exclusively from a (re-)emergence of totalitarianism, which can be understood as a continuum of twentieth century totalitarian politics. Essentially, the interpretation of democracy turns into a justification narrative for a degree of conservatism. Certainly, taking this viewpoint, democracy is nothing transformative: It has been achieved and deviations from the existing situation mean deviations for the worse. All one can do to promote democratic values is to defend existing institutions from external threats.

\section{Utopian democracy}


The alternative to treating democracy as the existing mode of government is to see it as an ideal. As an ideal, it has not been completely institutionalised, and indeed cannot be. The very point of utopia (at least in the non-absolutist sense) is that it can never be fully attained. If, then, democracy is seen in terms of utopia, it will only remain significant if it contains a vision of change. Democracy then is an idea which 'should be conceived as a good that only exists as good so long as it cannot be reached' (Mouffe 2005, 8). This interpretation then sees the threats to democracy as deriving from the loss of its utopian energy, while the liberal interpretation sees utopianism conversely as a threat. Perhaps indeed the best way to even defend democracy as it exists is to try to depart from it to the direction of an ideal.

How could democracy then be understood as an ideal? A straightforward way is to ground democracy on the principle of equality. Or in a stronger formulation, democracy is the antithesis of any form of power based on the superiority of an elite of any kind (Ranciere 2009). This means that within the not strictly private domain, all individuals should have an equal influence on the future form of the practices, institutions and principles that constitute this domain. Practically, given the existing hierarchies, mechanisms of exclusion and inequalities in participation, this is quite far from democracy as we know it.

Democracy is, then, 'anyone's power' or political power disregarding identities or personal characteristics. While typically institutionalised in the exclusive form of the nation-state, democracy in the utopian sense can be seen to be the call to empower the human being as such. Democracy is then based on the virtue of humanity as such: Neither acquired nor inherent qualities justify privileged positions. In addition, no power ascending above the community of equals (divinity, nobility, etc.) should have a position to influence the affairs of such community.

Antihierarchy translates organizationally as self-government. The democratic utopia could then be understood as a political community learning how to govern itself without hierarchies. Sometimes this requires emancipation to achieve political subjectivity, for example in independence movements, when the political subject understands that the external power is neither needed for governing nor legitimate. Typically, in contemporary capitalism, what is 
required is equalization of political skills through education. In ideal terms, learning selfgovernance extends to all material positions and identities and becomes a strong anti-elitist stance.

Thinking of 'democracies' as we know them, this very definition of democracy sounds strikingly radical, utopian, and revolutionary. These kinds of ideas for the extension of democratic principles are typically labelled 'radical democracy' (e.g. Little \& Lloyd 2009), even though it could as well be argued that they are rather only true to the idea of democracy, going to 'the root of democracy' (Laclau \& Mouffe 2001).

Yet understanding democracy in terms of utopia says nothing about its feasibility, at least in the short term. It is likely that people who are used to hierarchical organisations could not immediately adapt to a democratically organised society. It might be, that many modern institutions would be painstakingly difficult to organise democratically. The ideal therefore should be understood as, first, articulating a direction; and second, insisting on consistency.

Articulating a direction refers to the functions of utopia as showing a point towards which society should be moving, and the rationale of this movement. This point is very illuminatively made by Erik Olin Wright's metaphor of 'the compass' (Wright 2010, chapter 5), showing the general direction if not the exact path of where the society should be heading towards. Piecemeal changes then achieve a meaning when set in the context of this general direction. In the context of democracy in contemporary society, this means asking, how are existing hierarchies upheld, what makes the powers of different people to influence social reality so unequal And further, what kinds of changes could be made to the existing institutions and practices, here and now, to alter the situation.

Insisting on consistency in the context of democracy means that the need for democratic justification knows no fixed nor given limits. So, democracy as utopia can be articulated as an extension of principles on the basis of which some existing practices are organised. It is a call to apply democratic principles universally and consistently, understood as a direction for society to develop into. There is no reason why democratic politics should out of hand be confined to 
any predefined 'proper' domain, if other domains bear significance to social life, human wellbeing and relations between people.

Seen this way, democracy is not a form of government, but a principle which can be applied to assess and develop existing practices and institutions, or to imagine completely new ones. Categories such as the market and the state should not be seen as informing predetermined institutional arrangements. Rather, such categories and institutions, including the language used to describe them, should be kept open to democratic experimentation. Democratic practice should be based on the capacity to see beyond the existing language with its categorisations (see Hietalahti in this volume). This, in the words of Roberto Unger, ideally leads to 'empowered democracy' (Unger 1998). As an illuminating example, C. Douglas Lummis brought attention to the antidemocratic organisation of a factory by calling the assembly line an 'antidemocratic machine' (Lummis 1997, 79-110). While perhaps initially outlandish ('how could a machine be political?'), if the functioning of the assembly line depends on a hierarchical order, what is it if not an antidemocratic machine, and doesn't the task then constitute of conceiving democratic machines?

\section{Hegemonic democracy as a hybrid form}

What we today call democracies are representative of only one possible constellation, far from being throughout democratic. Yet this does not mean that the hegemonic model of democracy would be an outright hoax: Certainly the ideal has been partially realised. For example, voting, based on the idea of one vote each, anonymity, and the inalienability of voting rights, is a highly democratic practice. Democratic practices also abound in various kinds of contentious politics, experimental spaces and microdemocratic initiatives. Yet in other spheres of social organisation, quite other principles are applied: For instance, the organisation of a government office, a factory assembly line or a competitive market is without question very far from democratic organisation. 
The existing conception of democracy is more arbitrary than it seems. For example, classical ideas of democracy depart significantly from this contemporary conception, in their conception of the political body and the mode of participation. Furthermore, historical struggles for democracy have not limited themselves to the liberal capitalist conception, by for example demanding voting rights only. From ninteenth century socialist movements to the South African anti-apartheid struggle prior to the 1990s, the hope invested in the notion of democracy was clearly based on the idea of economic justice. (See for instance Slavin 2007 on Rosa Luxemburg, and The Congress of the People 1955).

Indeed, all existing 'democracies' are hybrid forms of government, containing both democratic and antidemocratic elements. As a hybrid model, contemporary capitalist liberal democracy constantly seeks balance between the egalitarian ideals of democracy and existing hierarchies. Yet this balance is not an outcome of arbitrary movement, but the capitalist elements of existing society enforce the anti-democratic elements: Therefore, merely protecting existing democratic spaces requires a push to demand a deeper democracy.

But then, looking at these hybrid forms, how exactly is the existing democratic model antidemocratic? The most visible characteristic is the compartmentalization of practices into distinct spheres of the 'political' and 'the economic'. This functions eventually to limit democratic politics into the realm of morality, identity and very small technical issuesSymptomatically, even democratic politics are often assessed from the basis of how politics abide with what is seen as 'neutral' knowledge on society and proper governance of capitalism. As a general notion, the problem related to this distinction was already captured by the old slogan 'democracy is stopped at the factory gate' (e.g. Heller \& Feher 1991, 107-110). But the scope of democratic politics is not only limited but can also further be narrowed down, as ever more matters significant to social life and individual well-being take place outside the realm of democratic decision-making. This highlights the essence of liberal capitalist democracy as a paradoxical form of democracy: It simultaneously celebrates the formal democratic procedure, but limits the impact democratic politics can have on society. Ever more people get to vote, but 
voting has ever less significance. (Which is not of course to say that it would have zero significance).

Practically, this can be seen in the superior position given to economic institutions. Part of the hegemonic understanding of democracy is that the scope of democratic politics can be limited by international economic agreements (in trade, investment, etc.), which gain a status comparable to a constitution: They are extremely hard to change by democratic means (Gill 1998, Schneiderman 2000). Further, key institutions such as central banks and ministries of finance are increasingly insulated from democratic politics (Mounk 2018; Berman \& McNamara 1999). The list could go on, but the point remains: The scope and influence of democratic politics in the existing constellation is quite limited, and could be limited further. Sometimes democratic politics can be close to completely lost to external powers, most noteworthily in the case of 'debtor states', in which the government has entered a debt trap, meaning that external debts accumulate and are not repayable, and creditors, de facto, dictate the policies of the country (e.g. Toussaint 2019).

\section{Limitations to democratic politics}

While democracy is kept alive by its utopian manifestations, the liberal capitalist approach to democracy silently justifies its increasing curtailment. Democratic spaces are not stable, but can contract, and indeed holders of economic power are typically very keen to see that such contraction takes place. If it is seen as legitimate that the experts, rather than a democratic body, decides on, say, central banking, despite its highly political nature, it is easy to apply this form of decision-making to decisions about budgets too. And so forth. If hierarchies are inevitable in organizing production, isn't it natural to apply them in the society more generally? Crucially, justification based on skill is highly different from justification based on democracy.

Antidemocratic ideas have existed throughout history, and there is no reason to believe that they would have suddenly vanished, even though they less often manifest today in the form of trying to deny the popular vote. These ideas can be roughly divided into elitism and belief in 
expertise. Elites have always perceived the 'masses' as incapable of governing themselves, and the elites themselves as enlightened leaders equipped with the appropriate character to rule. This reflects itself mostly in societies with steep class divisions, but practically everywhere. While elites might be for democracy, there remains a mentality that the correct 'dose' of democracy should be carefully administered, so that democracy does not produce unpredictable outcomes and disturb the existing social relations.

Second, contemporary capitalism is an inherently unstable system and requires (undemocratic) expert knowledge to maintain this stability. Investors can become frightened by the slightest unprecedented moves by central bankers; multinational enterprises are wary about investing if they do not get binding protections on their investments, overruling future democratic decisions; trade activity needs to be governed by complex sanctioned agreements; and financial markets are filled with securities, as everyone is seeking to get insurance on economic activities. Eventually political change becomes seen as primarily a 'political risk'. As often noted in contemporary criticism, contemporary society is dominated by the idea of technocratic governance based on expert knowledge on society, a 'promise to take politics out of policy' (e.g. Deleon \& Martell 2006). As experts possess the skill to administer a highly complex society, they typically see this skill informing also the claim to govern.

Meritocratic expert governance is considerably more successful than is mere authoritarianism. A good example is China, where claims to power are based on effective planning and market freedoms (more so than on brute force). Political legitimation then leans on the skills of the most capable and educated, instead of equality. From the perspective of such meritocracy, democracy is seen as dangerously unpredictable, casting political power to the unenlightened. (Bell 2015). The experienced need to govern capitalism predictably in the West and insulating key institutions from democratic influence is indeed closer to the Chinese mindset than Western democrats are happy to admit.

The hegemonic interpretation of democracy, that sees totalitarianism as the only existing threat to democracy, has difficulties in seeing increasing expert power and the concomitant diminishing of the democratic sphere as a threat to democracy. They are neither totalitarian 
politics nor questioning the formal democratic process. Yet noting these threats to democracy is particularly important as capitalism is developing into an antidemocratic phase: Perhaps contrary to the 1980 s, economic dynamism in the contemporary world is associated rather with the lack of democratic practices than their existence. As the connection between democracy and economic growth gets weaker, the true degree of valuation of democracy is revealed. In such circumstances, it is also necessary to be able to articulate the ideal form of democracy.

\section{The implications of liberalism}

As noted, another key element of the hegemonic form of democracy is its alignment with liberal individualism. This is reflected in the underlying understanding of the nature of society and democratic practice. In this understanding, society is understood as essentially a system of mediation of the wants and values of individuals existing independently of society. The individual with pre-existing wants and preferences is then taken as the 'entry point' for theory ${ }^{28}$. Thus, social practices and institutions are explained as an outcome of negotiation between these individuals, as they aim to mediate between their conflicting wants. This is where liberal theories of democracy, liberal theories of justice and neoclassical economics coincide $^{29}$.

The most noteworthy issue about individual-based ontology in this context is the difficulty to theorise social change. Seeing society as essentially an arbitrary group of individuals allows sophisticated theorising on negotiations of different kinds, but it is difficult to analyse, how individuals come together to bring about institutional change, and how people do conceive of alternative kinds of social orders. In the liberal conception of society, politics is essentially seen as a matter of defining the appropriate space for individual rights and for government

\footnotetext{
${ }^{28}$ All descriptions of social reality need an entry point, consisting of the basic ontological and methodological approach. Theoretical entry points cannot be assessed, so that ultimately a suitable method could be used to determine the superior entry point; rather they merely can be assumed, and the best one can do is to be aware of the consequences of this choice.

${ }^{29}$ Illuminatingly, for instance polling techniques used to predict electoral outcomes were invented for purposes off justifying marketing, promoting the idea that each individual has hidden wants that need to be brought to knowledge (Lears 1995).
} 
sovereignty. The prior sphere is where the individual solely decides based on preferences, wants and taste, and has no obligation to give any reasons for given choices. Government, on the other hand, is the sphere of legitimate coercion of existing individual wants.

Democracy, for its part, comes to be seen as essentially a method of conflict mediation. Democracy in then viewed as merely a mechanism of ordering wants, as they all cannot be met, as legislation is crafted and public funds are allocated to various and conflicting purposes. Indeed, as was discussed earlier in this book, politics today are often understood as an exercise of locating individuals within 'value maps' (see Eskelinen, Lakkala and Pyykkönen in this volume). Possible political positions are then reflected as dots in space organised along the axes of right-left and liberal-conservative. This kind of spatial representation of politics ultimately implies that people are ontologically separate and the axes are given.

While this interpretation of democracy does capture relevant aspects of it, other highly important aspects are bracketed by the underlying ontology. When seen as mediation and determining relations between rights and sovereignty, democracy surpasses matters such as learning and development (people can learn horizontal social relations, rather than just pushing their wants), and collective action for social change (human beings are just not individuals with values, but come together to promote new ideas and experiment on them). In other words, the individualist ontology has difficulties recognising the existence and relevance of utopian ideas and practices. Or, in other words, it is stuck with mediating between 'private hopes', as a deeply democratic sentiment only gets born out of 'public hope' (Lummis 1997, 154-157).

\section{Open future and the significance of imagination}

The definition of ideal democracy can be complemented with one significant underlying notion: Open future. This means that in utopian democracy, only the (egalitarian) political community has the power to decide over its future fate. The practices and ideas described above are all obstacles to the ideal of the egalitarian community having the power and responsibility over its future. As the future has become a terrain of political struggle, antidemocratic forces aim at 
defining the future to the broadest possible extent (expert power), setting priorities that need to be followed in the future as well (e.g. sanctioned investment treaties limiting democratic decision-making), or defining the imaginative framework for future politics (the 'axes' of values). The counterpower to these forces is the democratic spirit, struggling to keep the future open to democratic will against both conservative institutions and conservative knowledge production.

Democracy, by nature, is unpredictable, and indeed a legitimate approach to current democracy is that it is motivated by the need to 'take risk out of democracy' (Carey 1996). Unpredictability emphasises the aspect of responsibility inherent in democracy. The political body cannot escape deciding its own fate. If the influence of democratic politics is highly restricted, the result is increasing indifference towards politics in general.

As noted before (see Lakkala in this volume), utopias have a function of 'disrupting' the present, which allows seeing a multiplicity of possible open futures. By further providing 'critical counter-images', utopias assist critical reflection on existing society. This is crucial to democracy; a functioning democracy is not only a system of value mediation, but a system of weighing and constructing future alternatives too. This requires that people have the (psychological and cultural) means to construct, compare and critically reflect ideas of what a society could be.

Mere articulation of 'values' is not sufficient, especially if piecemeal change is seen as the exclusive content of politics. Even if politics often functions through such changes, the changes need to be motivated by and connected to broader ideas of a possible society in order to remain significant. If this is not the case, the fear is that democracy is dwarfed into a technical system organised by technical rationality (e.g. Marcuse 1964), with no deeper idea of sense or direction. The technical and formal mode of thought gains dominance over the critical, holistic and reflexive. Politics collapsed into mere governance produces exactly mere technical governance and optimization without articulated purpose. (See also Nussbaum 2010 on technical rationality and education). Democratic practice is lost in conjuncture with a broader sense of purpose in society. 
If democracy is seen in a broader sense than mediating between ontologically self-contained individuals, political imagination becomes highly important. As noted several times in this book, the political imaginative capacity has been in retreat. In liberal capitalist democracy, not only the possibilities to enact institutional change are limited, but so too are the possibilities to imagine alternative institutions. While technocratisation and the lack of political imagination are distinct phenomena, they should be analysed as a part of the same phenomenon, as elements feeding into a vicious circle. A society of 'capitalist realism' (Fisher 2009) undermines the capacity to imagine alternatives, and conversely, when the capacity to imagine alternatives gets weaker, governance steadily replaces politics. Seen this way, the precondition of a functioning democracy is that people have the proper imaginative skills to conceive of utopias, and capacities to form and develop these products of imagination collectively.

\section{Saving the utopian potential of concepts and ways forward}

The project of saving and re-articulating the utopian potential of democracy is an example of a possible utopian strategy within contemporary capitalism. It means to analyse commonplace ideas and ask: Could they still inform hope of radical transformation, despite being diluted, compromised and constrained in the process of their institutionalization? This comes close to what Ruth Levitas called 'the archeological mode' of utopianism: Identifying utopian elements in what is otherwise seen as pragmatic or non-utopian (Levitas 2013, 153). Also, one might hear an echo of Ernst Bloch, who sought to find a utopian spirit and expressions of hope in a myriad of contemporary forms of expression (Bloch 1986). Yet the matter with democracy is somewhat different: It is not a pragmatic idea as such, only it has been neutralized. As Wright (2010) tries to map 'real utopias' in the sense of utopian and achievable, the task here is to seek the utopian in the ostensibly achieved.

Democracy is as a brilliant example of a concept which can benefit from this kind of approach. Indeed, despite the apparent radicalism of interpreting democracy as insisting on equality, it has often been noted that democracy rests on the idea of the fundamental equality between 
human beings, which is deeply inscribed in the Western tradition of political philosophy (Dahl $1989,84-88)$. In the case of democracy, mere consistency can inform a radical programme.

A key theoretical input in the attempts to rediscover the transformative potential in the liberal use of concepts is Laclau and Mouffe's work on radical democracy. They set out exactly to broaden the remit of liberal democratic principles such as liberty and equality (Laclau and Mouffe 1998). In their words, the problem with 'actually existing' liberal democracies is their incorporated system of power which redefines and limits the operation of those values (Laclau and Mouffe 2001, xv). ${ }^{30}$ The task is to separate the values of democracy from the distorting effects of this system of power, described above as consisting of hierarchies, technocratic rule and governance through detached individuality. A large number of similar concepts have a similar kind of potential to be reclaimed. For example, freedom, equality, and rights have all carried out substantially more transformative meaning, but then been incorporated into the existing framework and lost their utopian potential, at least to a large extent. (See e.g. McNeilly 2016 on radical interpretations of human rights).

Seeing achieved democratic progress assists in seeing the present as a point in a continuum between absolute hierarchy and ideal democracy. Indeed, when looking at the history of democracy, highly pivotal democratic developments have taken place within democratic revolutions such as the end of the Cold War. This applies also culturally: Still not so long ago, the 'layman' was seen as essentially unfit for democratic decision-making. The universalization of education systems has had a remarkable effect on the equalization of democratic participation. Also, there has been a remarkable change in gender relations, largely undoing the situation in which half of humanity was blocked from political participation. From the perspective of society a hundred years ago, current democracy could have appeared as a risky attempt to give power to the unfit. There is no reason why further steps in the direction of 'anyone's governance' could not be taken.

\footnotetext{
${ }^{30}$ Not everyone shares this optimism towards "rescuing concepts'. Rancière, for example, has been highly sceptical of attempts to maintain liberalism or its resources in any form (Chambers 2013, 10-14).
} 
Promisingly, new initiatives have recently revitalized a discourse on developing democracy within countries that have used to see themselves as self-evidently democratic. These include, for example, participatory decision-making mechanisms such as participatory budgeting (Baiocchi 2001) and direct democracy (Kaufmann, Büchi \& Braun 2010), along with global democracy initiatives (Teivainen \& Patomäki 2004) and experiments (in the World Social Forum as an experiment in global and participatory democracy, see Smith et al., 2014). Yet even perhaps more importantly, new movements have highlighted issues related to the common ownership of resources (McLaren \& Agyeman 2015). More generally, the distinction between democracy and economy is continuously contested, by for example showing how economic exclusion leads to democratic exclusion (McLaren \& Agyeman 2016, 76-77).

Sometimes new democratic initiatives stem from new economic forms such as the 'solidarity economy'. For example, Ethan Miller asks, 'Could a process of horizontal networking, linking diverse democratic alternatives and social change organizations together in webs of mutual recognition and support, generate a social movement and economic vision capable of challenging the global capitalist order?' (Miller 2019). All in all, current (counter-)political discourse is rich with initiatives with significance to democracy. Yet most of such initiatives relate to grassroot organisation or contained spaces (for an exception see Albert \& Hahnel 1991 on participatory economics). The challenge is then, how to diffuse the new practices, pedagogies and ontologies experimented with in these contained spaces to inform broader institutions.

\section{Conclusions}

This book began with a complaint on the existing state of utopian thought. Current liberal democratic capitalism involves a number of institutions, practices and mindsets that, along with the general cultural mood, significantly curtail imagination on societal alternatives. As noted in this chapter, one of the mechanisms of this curtailment is the dilution of radical concepts. While people have long fought for democracy, liberty, freedom of speech, and so forth, liberal 
capitalism materialises some limited aspects of these ideals and presents itself as the ultimate incarnation of the ideals. Therefore, a possible approach for formulating political utopias is to try to 're-radicalise' such concepts which have been subject to recuperation, rather than distancing oneself completely from the vocabulary dominating current politics.

Above, I have discussed a notion of radical (or consistent) democracy, in order to show how widely accepted democratic principles could lead to highly radical conclusions. Except for radical departures from the existing order, it is important to see utopian articulations of democracy necessary for even the continued existence of democracy as we know it, as the democratic space is always under pressure. This pressure derives from the system of power consisting of economic interests and technocratic governance, and the interpretation of democracy as a mediation space between ontologically unattached individuals. Democracy has to be on the move towards deeper democracy, articulated as a motivating but unattainable ideal; or, in other words, 'the horizon for democracy is the impossibility of the full realisation of democracy itself' (McNeilly 2016).

The energy for democracy comes from the quest for transitions to equality, and conversely, when democracy declares itself 'achieved', it ceases to be in motion, loses its utopian spirit, and goes into retreat. Furthermore, democratic practice is dependent on (collective) learning, communication, deliberation and public criticism. Without a utopian sentiment, democratic deliberation becomes devoid of substantial content. Yet while democracy is far from being realized in the currently existing self-declared democracies, it can be seen as something of a 'limited realised utopia'. While strong societal forces currently curb its further realisation, contemporary hybrid democracy clearly has democratic spaces and practices. This leads to a need to see the radical and utopian elements in the self-evident, given and widely accepted. As noted above, this approach can be taken as a method to analyse other concepts as well from the perspective of rearticulating their transformative potential.

\section{References}


Albert, M. \& Hahnel, R. (1991) The political economy of participatory economics. Princeton: Princeton University press.

Baiocchi, G. (2001). 'The Porto Alegre Experiment and Deliberative Democratic Theory'. Politics \& Society $29,43-72$.

Bell, D. (2015) The China model. Political meritocracy and the limits of democracy. Princeton, NJ: Princeton University Press.

Berman, S. \& McNamara, K. (1999) 'Bank on democracy. Why central banks need public oversight'. Foreign affairs 78 (1), 2-8.

Carey, A. (1996) Taking the risk out of democracy. Chicago: University of Illinois press.

Chambers, S. 2013. The lessons of Rancière. Oxford: Oxford University Press.

Congress of the people (1955) The freedom charter. Available at http://www.historicalpapers.wits.ac.za/inventories/inv pdfo/AD1137/AD1137-Ea6-1-001jpeg.pdf

Dahl, R. (1989) Democracy and its critics. New Haven: Yale University press.

Deleon, P. \& Martell, C. (2006) 'The policy sciences: past, present and future'. In B. Peters \& J. Pierre (eds.) Handbook of public policy. Thousand Oaks, CA: Sage.

Fisher, M. (2009) Capitalist Realism. Is There No Alternative? Winchester/Washington: 0 Books.

Fukuyama, F. (1989) 'The End of History?' The National Interest 16, 3-18.

Gill, S. (1998) 'New constitutionalism, democratisation and global political economy.' Pacifica review: Peace, security and global change 10 (1), 23-38.

Harcourt, B. (2011) The illusion of free markets. Punishment and the myth of natural order. Cambridge, Mass: Harvard University Press. 
Held, D. (2006) Models of democracy. Cambridge: Polity Press.

Heller, A. \& Feher, F. (1991) The grandeur and twilight of radical universalism. New Brunswick: Transaction publishers.

Jameson, F. (1991) Postmodernism, or, the cultural logic of late capitalism. Duke University press.

Kaufmann, B., Büchi, R. \& Braun, N. (2010) Guidebook to direct democracy - in Switzerland and beyond. Marburg: Initiative \& Referendum Institute Europe.

Laclau, E. \& Mouffe, C. (2001) Hegemony and Socialist Strategy: Towards a radical democratic politics, 2nd ed. London: Verso.

Laclau, E. \& Mouffe, C. (1998) 'Hegemony and socialism: An Interview with Chantal Mouffe and Ernesto Laclau'. Palinurus. http://anselmocarranco.tripod.com/id68.html.

Lears, J. (1995) Fables of abundance. A cultural history of advertising in America. New York: Basic Books.

Little, A. \& Lloyd, M. (2009) The politics of radical democracy. Edinburgh: Edinburgh University press.

Lummis, C. D. (1997) Radical democracy. Ithaca, NY: Cornell University press.

Marcuse, H. (1964) One-dimensional man: studies in the ideology of advanced industrial society. London: Routledge \& Kegan Paul.

McLaren, D. \& Agyeman, J. (2015) Sharing Cities. Cambridge MA: MIT Press.

McLaren, D. \& Agyeman, J. (2016) 'Sharing Cities: Governing the City as Commons'. In J. Ramos (ed.) City as commons. A policy reader. Melbourne: Commons transition coalition, pp. 77-79.

McNeilly, K. 2016. 'After the critique of rights: for a radical democratic theory and practice of human rights'. Law and critique 27 (3), 269-288. 
Miller, E. (2019) 'Other Economies Are Possible!': Building a Solidarity Economy.

http://www.geo.coop/node/35

Mouffe, C. 2005. The return of the political. London: Verso.

Mounk, Y. (2018) 'The undemocratic dilemma'. Journal of democracy 29 (2), 98-112.

Nussbaum, M. (2010) Not for profit. Why democracy needs the humanities. Princeton: Princeton University press.

Rancière, J. (2009) Hatred of democracy. London: Verso.

Schneiderman, D. (2000) 'Investment rules and the new constitutionalism'. Law \& Social Inquiry $25(3), 757-87$.

Slavin, P. (2007) 'Rosa Luxemburg's concept of democracy'. Proceedings of the 15th International Rosa Luxemburg Conference. Tokyo: Chuo university. http://www2.chuou.ac.jp/houbun/sympo/rosa confe2007/pdf/papers/Slavin.pdf

Smith, J. et al. (2014) Global democracy and the World social forum. Boulder \& London: Paradigm publishers.

Teivainen, T. \& Patomäki, H. (2004) A possible world. Democratic transformation of global institutions. London: Zed books.

Toussaint, E. (2019) The debt system. A history of sovereign debts and their repudiation. Chicago: Haymarket.

Unger, R. M. (1998) Democracy realized. The progressive alternative. London: Verso. 